\title{
SELF EFICACY DAN BERPIKIR POSISTIF DENGAN KECEMASAN BERBICARA DI DEPAN UMUM PADA MAHASISWA
}

\section{POSITIVE THINKING AND SELF EFFICACY ON ANXIETY IN PUBLIC SPEAKING IN STUDENTS}

\author{
Nurhasanah \\ Fakultas Kesehatan, Universitas Muhammadiyah Pringsewu \\ Email: khazanah@umpri.ac.id
}

\begin{abstract}
Positive Thinking And Self Efficacy On Anxiety In Public Speaking In Students Students are required to be able to speak in public. The ability to speak in public will make it easier for students to convey ideas, or suggestions and become a value-added skill for them. Based on the literature study, there are several factors that influence public speaking anxiety, including self-efficacy and positive thinking skills. This study aims to determine the relationship between self-efficacy and positive thinking with public speaking anxiety in college students. This study uses a quantitative design with a cross-sectional approach. The sample in this study was 67 nursing students in the fifth semester of 2019. The results obtained $(r)=-0.647$ and $p$ value $<0.001$ which indicates a very significant negative relationship between the variables of public speaking anxiety and self-efficacy. The correlation between the variables of public speaking anxiety and positive thinking is $(r)=-0.703$ and $\mathrm{p}$ value $<0.001$ which indicates a very significant negative relationship between public speaking anxiety and positive thinking. The higher self-efficacy and positive thinking, the lower the anxiety of students to speak in public for STIKes Muhammadiyah Pringsewu students.
\end{abstract}

Keywords: self efficacy, positive thinking, public speaking anxiety, students

\begin{abstract}
Abstrak: Berfikir Posistif Dan Self Eficacy Dengan Kecemasan Berbicara Di Depan Umum Pada Mahasiswa Mahasiswa dituntut untuk mampu berbicara di depan umum. Kemampuan berbicara di depan umum akan memudahkan mahasiswa untuk menyampaikan ide, atau saran dan menjadi keterampilan yang bernilai tambah bagi mereka. Berdasarkan studi literatur ada beberapa faktor yang mempengaruhi kecemasan berbicara di depan umum, termasuk efikasi diri dan kemampuan berfikir posifif. Penelitian ini bertujuan untuk mengetahui hubungan antara self eficacy dan berpikir posistif dengan kecemasan berbicara di depan umum pada mahasiswa. Penelitian ini menggunakan desain kuantitatif dengan pendekatan crossectional. Sampel pada penelitian ini berjumlah 67 orang mahasiswa keperawatan semester lima tahun 2019. Hasil penelitian didapatkan $(\mathrm{r})=-0,647$ dan $p$ value $<0,001$ yang menunjukkan adanya hubungan negatif yang sangat signifikan antara variabel kecemasan berbicara di depan umum dengan efikasi diri. Hasil korelasi antara variabel kecemasan berbicara di depan umum dan berpikir positif adalah $(\mathrm{r})=-0,703$ dan $p$ value $<0,001$ yang menunjukkan adanya hubungan negatif yang sangat signifikan antara kecemasan berbicara di depan umum dengan berpikir positif. Semakin tinggi self efficacy dan berfikir positif maka akan semakin menurunkan kecemasan mahasiswa untuk berbicara di depan umum bagi mahasiswa STIKes Muhammadiyah Pringsewu
\end{abstract}

Kata Kunci : self efficacy, berfikir positf, Kecemasan bicara didepan umum, mahasiswa,

\section{PENDAHULUAN}

Kemampuan berbicara di depan umum tidak sepenuhnya dimiliki oleh pembicara publik. Setiap orang memiliki kesempatan yang sama untuk berbicara di depan umum, seperti Master of Ceremony (MC), Presenter atau Moderator, yang meliputi siswa. Mahasiswa dituntut untuk mampu berbicara di depan umum. Kemampuan berbicara di depan umum akan memudahkan mahasiswa untuk 
menyampaikan ide, atau saran dan menjadi keterampilan yang bernilai tambah bagi mereka. Tidak semua mahasiswa mampu berbicara di depan umum. Salah satu penyebab kesulitan berbicara di depan umum karena mahasiswa memiliki kecemasan dalam menyampaikan informasi terutama di depan umum (Bukhori, 2016).

Mc Croskey menyatakan bahwa kecemasan berbicara di depan umum merupakan bagian dari ketakutan komunikasi atau communication anxiety. Reaksi yang muncul adalah gugup, cemas, khawatir, dan takut melakukan kesalahan. Kecemasan berbicara di depan umum terjadi ketika seseorang berpikir bahwa dia tidak yakin mampu mengendalikan situasi yang dihadapinya, dan akibatnya, tidak dapat fokus dan merasa gelisah. Seseorang dengan kepercayaan diri yang tinggi dan tingkat kecemasan berbicara di depan umum yang rendah sangat berlawanan, seperti yang ditunjukkan dalam banyak penelitian. (McCroskey, 2013)

Mahasiswa yang mengalami kecemasan berbicara di depan umum akan mengarahkan mereka untuk tidak presentasi, menurunkan frekuensi dan intensitas keterlibatannya dalam transaksi berbicara di muka umum, sehingga dirinya akan menghindari situasi berbicara di muka umum. Keinginan untuk menghadapi kecemasan, tidak dilakukan oleh banyak orang, mereka cenderung untuk melakukan tindakan menghindar dari masa- lah yang sedang dihadapi. Bandura (1997) mengemukakan, bahwa individu yang mengalami kecemasan menunjukkan ketakutan dan perilaku menghindar yang sering mengganggu performansi dalam kehidupan mereka, begitu pula dalam situasi akademik(Wahyuni, 2015)

Menurut Penelitian Bukhori, (2016), kecemasan berbicara di depan umum dapat dialami oleh semua orang tak terkecuali mahasiswa. Kecemasan tersebut memiliki pengaruh negatif pada diri seorang mahasiswa baik ketika masih duduk di bangku kuliah maupun ketika sudah lulus kelak. Ketika masih kuliah, terutama yang menekuni bidang sosial keagamaan seperti ilmu dakwah, seorang mahasiswa yang memiliki permasalahan kecemasan berbicara di depan umum akan sulit untuk memiliki prestasi akademik yang sangat tinggi. Hal tersebut dapat dipahami karena dalam proses belajar mengajar, salah satu metode yang sering digunakan dosen adalah diskusi, sehingga kemampuan berbicara di depan umum sangat dibutuhkan. Seseorang dengan kecemasan berbicara di depan umum, kendati sudah lulus dan memiliki ijazah, dimungkinkan akan mengalami kendala dalam melamar pekerjaan tertentu, terlebih pekerjaan yang menekankan pada kemampuan atau keahlian berbicara di depan orang banyak.

Menurut penelitian Muslimin and Mahasiswa, (2013) bahwa faktor-faktor yang memengaruhi kecemasan berkomunikasi di depan umum yaitu perasaan sedang dievaluasi, merasa orang lain memiliki kemampuan berkomunikasi yang lebih baik, dan kurangnya kemampuan dan pengalaman dalam berkomunikasi. Factor laindiantaranya adalah self efficacy dan emosi. Kecemasan berbicara di depan umum merupakan fungsi rendahnya self-efficacy. Faktor kematangan emosi yang ditandai dengan kemampuan berfikir positif dan negated untuk tidak meledakkan emosi di hadapan orang lain, penilaian situasi kritis dan memiliki emosi yang stabil.(Wahyuni, 2015).

Menurut Bandura (1985;1995), self-efficacy adalah keyakinan seseorang bahwa ia mampu berpikir, mendorong motivasi dan mampu mengendalikan situasi dalam rangka mencapai kesuksesan. Efikasi diri juga kemampuan mereka untuk atau mengatur dan melaksanakan tindakan yang diperlukan untuk mengelola situasi prospektif.Keyakinan self-efficacy tidak hanya pada harapan orang untuk memperoleh pengetahuan dan keterampilan tetapi juga harapan mereka untuk mengatasi masalah dan mewujudkan tindakan tertentu yang diperlukan untuk mencapai di bawah tekanan sosial dan kesusahan. (Gündüz, 2012). Dengan kata lain, orang harus memiliki keyakinan efikasi diri, selain dari pengetahuan dan keterampilan, yang memungkinkan mereka untuk menerapkan pengetahuan dan keterampilan ke dalam praktik secara efektif untuk tampil dalam kehidupan dengan sukses

Pola pikir individu sangat membantu dalam mengatasi masalah yang berhubungan dengan suasana hati (mood), seperti depresi, kecemasan, kemarahan, kepanikan, kecemburuan, rasa bersalah dan rasa malu. Apabila seseorang mempunyai pola pikir yang positif maka individu tersebut dapat mengatasi masalah yang berhubungan dengan suasana hati. Sebaliknya apabila seseorang mempunyai pola pikir yang negatif, maka individu tersebut cenderung menjadi depresi, cemas, panik, muncul perasaan bersalah, yang pada akhirnya akan mengganggu interaksi sosialnya (Arsy, 2011). 
Berpikir negatif memberikan pengaruh buruk yang lebih besar dari dampak positifnya, berpikir negatif juga menyebabkan seseorang tertekan dan kehilangan banyak energi, dampak yang lebih buruk dari berpikir negatif yaitu mengakibakan manusia tidak mampu lagi berbuat sesuatu untuk menciptakan prestasi. situasi ini dapat berdampak pada saat mahasiswa tampil berbicara agar bahasan yang akan disampaikan pada waktu berbicara didepan umum dapat dipahami, mahasiswa harus berbipikir positif. Dengan berpikir positif, secara otomatis akan memengaruhi jiwa manusia menjadi lebih optimis, imajinasi menjadi lebih kreatif, dan semangat menjadi semakin kuat (Mardhika, 2016).

Berdasarkan hasil survei awal yang peneliti lakukan pada mahasiswa STIKes Muhamamdiyah Pringsewu tahun 2019, ditemukan bahwa faktor lain yang menyebabkan mahasiswa mengalami kecemasan ketika berbicara di depan umum adalah keyakinan yang kurang dan sulitnya mengontrol pikiran positif saat berbicara di depan umum. Lima belas dari dua puluh mahasiswa mengaku tidak percaya diri ketika harus presentasi ataupun berbicara di depan kelas terutama berbicara langsung dihadapan dosen. Kemampuan berkomunikasi menjadi kebutuhan utama yang harus dimiliki oleh semua orang khususnya bagi mahasiswa kesehatan agar menjadi lebih kompeten saat memberikan pendidikan kesehatan di depan umum. Penelitian ini bertujuan untuk mengetahui hubungan antara berpikir posistif dengan self eficacy terhadap kecemasan berbicara di depan umum pada mahasiswa.

\section{METODE}

Metode penelitian yang digunakan dalam penelitian ini adalah metode penelitian kuantitatif. Penelitian ini menggunakan pendekatan crossectional (Dharma, 2015). Variabel independen dalam penelitian ini adalah self efficacy dan berfikir positif. Sedangkan variabel dependen dari penelitian ini adalah kecemasan berbicar di depan umum. Penelitian ini dilakukan pada mahasiswa keperawatan semester V STIKes Muhamamdiyah Pringsewu pada Desember tahun 2019. Populasi penelitian ini adalah 110 orang dan sampel pada penelitian ini adalah 67 orang. Alat ukur yang digunakan untuk mengukur Self Efficacy diukur menggunakan skala Self Efficacy yang disusun berdasarkan aspekaspek Self Efficacy yang dikemukakan oleh Bandura (2004), yaitu percaya pada kemampuan sendiri, kesanggupan menyelesaikan tugas dan ke- sanggupan untuk mengatasi rintangan. Kuesioner terdiri dari 27 item pernyataan. 13 item pernyataan favorable dan 14 itemitem pernyataan unfavorable. Pengunaan alat ukur untuk mengukur kecemasan berbicara di depan umum menggunakan skala kecemasan berbicara di depan umum yang disusun peneliti berdasarkan aspek-aspek kecemasan berbicara di depan umum yang dikemukakan oleh Rogers (2004), ya-itu komponen fisik, komponen kognitif, komponen emosional dan perilaku. Proses pengukuran skala kecemasan berbicara di depan umum menggunakan model/pola skala Likert. Skala kecemasan berbicara di depan umum terdiri dari 25 item pernyataan. 11 item pernyataan favorable dan 15 item pernyataan unfavorable.(Wahyuni, 2015). Penelitian ini menggunakan analisis korelasi product moment (Sugiyono, 2016).

\section{HASIL}

Berdasarkan hasil pada uji normalitas menggunakan Kolmogorov Smirnov pada variabel kecemasan berbicara di depan umum didapatkan nilai > 0,05 yakni 0,168 hal ini menandakan sebaran data normal.

Tabel 1. Hasil Uji Linearlitas Hubungan self efficacy dengan kecemasan berbicara di depan umum pada mahasiswa

\begin{tabular}{ll}
\hline Mean $(\mathrm{SD})$ & P value \\
\hline $48,27(8,3673)$ & 0,09 \\
\hline
\end{tabular}

Hasil dari uji linearitas dapat dilihat pada anova table bagian deviation from linearity. Pada uji linearitas didapatkan nilai mean dengan total 48,27 dan Std. Deviaton dengan total 8,3673 . Hasil dari uji linearitas antara variabel kecemasan berbicara di depan umum dan efikasi diri didapatkan nilai 
yang > 0,05 yakni 0,090 yang menunjukkan variabel kecemasan berbicara di depan umum dan efikasi diri memiliki hubungan yang searah atau linear.

Tabel 2. Hasil Uji Linearitas Hubungan berfikir positif dengan kecemasan berbicara di depan umum pada mahasiswa

$\overline{P \text { value }}$

Uji linearitas antara variabel kecemasan berbicara di depan umum dan berpikir positif didapatkan nilai yang > 0,05 yakni 0,522 yang menunjukkan bahwa variabel kecemasan berbicara di depan umum dan berpikir positif memiliki hubungan yang searah atau linear.

Berdasarkan uji asumsi yaitu uji normalitas dan uji linearitas telah terbukti normal dan linear, hal ini telah memenuhi syarat untuk melakukan teknik analisis regresi berganda. Berdasarkan pada tabel korelasi diperoleh hasil korelasi antara kecemasan berbicara di depan umum dan efikasi diri adalah $(\mathrm{r})=-0,647$ dan $p$ value $<0,001$ yang menunjukkan adanya hubungan negatif yang sangat signifikan antara variabel kecemasan berbicara di depan umum dengan efikasi diri. Dari hasil tersebut dapat disimpulkan bahwa hipotesis minor peneliti diterima.

Hasil uji statistik juga diperoleh juga hasil korelasi antara variabel kecemasan berbicara di depan umum dan berpikir positif adalah $(\mathrm{r})=-0,703$ dan $p$ value $<0,001$ yang menunjukkan adanya hubungan negatif yang sangat signifikan antara kecemasan berbicara di depan umum dengan berpikir positif. Dari hasil tersebut dapat disimpulkan bahwa hipotesis minor penelitian diterima. Kemudian untuk hipotesis mayor dapat dilihat dari tabel anova yakni $\mathrm{F}$ hitung 50,412 dengan $p$ value $<0,001$ yang menunjukkan adanya hubungan yang sangat signifikan antara variabel efikasi diri dan berpikir positif terhadap kecemasan berbicara di depan umum yang menunjukkan bahwa hipotesis mayor peneliti diterima.

\section{PEMBAHASAN}

Pada penelitian ini didapatkan korelasi antara self efficacy dengan kecemasan berbicara di depan umum $(r)=-0,647$ dan $p$ value $<0,001$. Hal ini berarti ada hubungan yang kuat antara self efficacy dengan kecemasan berbicara di depan umum pada mahasiswa

Berbicara di depan umum adalah bentuk dari pengembangan percakapan di mana jumlah pendengar yang lebih banyak dengan tujuan menyampaikan sebuah informasi melalui tatap muka langsung.(Bukhori, 2016) Menurut Leary dan Kowalsky, kecemasan berbicara di publik adalah salah satu kecemasan sosial yang paling umum dan merupakan bagian dari kecemasan sosial.(McCroskey, 2013)

Berdasarkan studi yang dilakukan tentang keyakinan efikasi diri, orang dapat mengembangkan keyakinan efikasi diri spesifik di berbagai bidang seperti matematika, komunikasi, sains, kehidupan sosial, olahraga, dan kemampuan berbicara di depan umum.(Gündüz, 2012)

Seseorang yang memiliki kepercayaan diri tinggi akan memiliki keberanian untuk mengeluarkan pendapat di depan umum, karena ia memiliki kemampuan untuk mengendalikan emosi ketika sedang dalam tekanan tertentu. Ia juga mampu menguasai dirinya dalam bertindak dan dapat menentukan saat yang tepat untuk melakukan suatu tindakan dalam menyelesaikan suatu permasalahan yang dihadapinya (Bukhori, 2016)

Hasil ini sejalan dengan penelitian (Wahyuni, 2013) yang menyatakan bahwa ada hubungan yang signifikan antara kecemasan berbicara di depan umum dan kepercayaan diri di antara siswa dari departemen Psikologi kelas 2009 dan 2010, dengan $r=-0559$ R2 $=32,5$ dan $p=0,000$. Hal ini juga berarti semakin tinggi kepercayaan diri maka semakin rendah kecemasan berbicara di depan umum, dan begitu pula sebaliknya, semakin rendah kepercayaan diri maka semakin tinggi kecemasan berbicara di depan umum pada mahasiswa. 
Didukung oleh penelitian Haziqatuzikra and Nio, (2018) yang menyatakan bahwa penelitian menunjukkan koefisien korelasi (r) sebesar -0.518 dan nilai $\mathrm{p}=0,000$. Hal ini berarti terdapat hubungan hubungan signifikan antara self-efficacy dengan kecemasan berbicara di depan umum. ni berarti semakin tinggi self-efficacy pada diri seseorang maka akan semakin rendah tingkat kecemasan seseorang saat berbicara di depan umum. Individu yang memiliki self-efficacy rendah cenderung menghindari tugas. Self-efficacy sangat dibutuhkan oleh mahasiswa dalam menyelesaikan tugasnya (berbicara di depan umum).

Pikiran yang tegang membuat mahasiswa tidak konsentrasi ketika berbicara di depan banyak orang, mengalami kebingungan dan tidak tahu apa yang harus dilakukan ketika tiba gilirannya untuk berbicara. Perasaan mahasiswa yang merasa dirinya terancam dan mempersepsikan kegiatan berbicara di depan umum sebagai masalah besar membuat mahasiswa khawatir, gelisah dan takut sehingga dalam situasi tersebut mahasiswa akan mengalami rasa cemas menghadapi berbicara di depan umum. Kondisi sangat cemas membuat mahasiswa tidak bisa mengendalikan perilaku motoriknya, sehingga muncul reaksi gemetar, gugup, saat berada dalam situasi berbicara di depan banyak orang. Tidak terkendalinya manifestasi gejala fisik, proses mental, dan gejala emosi tersebutlah yang membuat mahasiswa mengalami kecemasan ketika berbicara di depan umum.

Berdasarkan uraian di atas dapat diambil pemahaman bahwa salah satu hal yang memengaruhi kecemasan berbicara di depan umum adalah rendahnya self efficacy yang ada dalam diri seseorang. Mahasiswa yang memiliki self efficacy rendah tidak memiliki keyakinan akan kemampuannya dalam menyampaikan gagasannya di depan umum, sehingga menyebabkan perasaannya tertekan. Perasaan tersebut dapat mengakibatkan seseorang menjadi pusing kepala, mengeluarkan keringat secara berlebihan, dan perutnya menjadi mual, atau dengan kata lain mahasiswa tersebut mengalami kecemasan berbicara di depan umum.

Selain dipengaruhi self efficacy, kecemasan berbicara di depan umum juga dipengaruhi oleh berfikir positif mahasiswa. diperoleh juga hasil korelasi antara variabel kecemasan berbicara di depan umum dan berpikir positif adalah $(\mathrm{r})=-0,703$ dan $p$ value $<0,001$ yang menunjukkan adanya hubungan negatif yang sangat signifikan antara kecemasan berbicara di depan umum dengan berpikir positif. Semakin seseorang berpikir positif maka semakin rendah kecemasan berbicara di depan umum, sebaliknya semakin seseorang berpikir negatif maka akan semakin tinggi kecemasan berbicara di depan umum. Hal ini dapat disebabkan karena individu membangun pesanpesan yang negatif dan memperkirakan hal-hal yang negatif sebagai hasil keikutsertaannya dalam interaksi komunikasi.

Berpikir positif dapat dideskripsikan sebagai suatu cara berpikir yang lebih menekankan pada sudut pandang dan emosi yang positif, baik terhadap diri sendiri, orang lain maupun situasi yang dihadapi. pola pikir positif merupakan kecenderungan individu untuk memandang segala sesuatu dari segi positifnya dan selalu berpikir optimis terhadap lingkungan serta dirinya sendiri. Pola pikir inilah yang dapat membantu individu dalam mengatasi masalahnya (Elfiky, 2009).

Penelitian ini sejalan dengan Prakoso, (2014) menunjukkan ada hubungan negatif ( $r x y=-0,589$ $, p=0,000(p<0,01))$ yang sangat signifikan antara berpikir positif dengan kecemasan berbicara di depan umum. Semakin tinggi berpikir positif maka semakin rendah kecemasan berbicara di depan umum, demikian pula sebaliknya semakin rendah berpikir positif maka semakin tinggi kecemasan berbicara di depan umum.

Didukung oleh penelitian Adriansyah, Rahayu and Prastika, (2015) yang mengatakan Ada penurunan kecemasan pada subjek setelah diberikan terapi berpikir positif dengan nilai $\mathrm{U}=62.000$ dan $\mathrm{p}=0.000$. Cara berpikir seseorang, negatif atau positif, akan mempengaruhi sikap dan perilakunya, maupun dalam mengambil pilihan tindakan. pikiran memiliki pengaruh terhadap sikap dan perilaku. Sikap terdiri dari komponen kognitif dan afektif. Pikiran menekankan komponen afektif untuk menghasilkan penilaian dan perkiraan mengenai perwujudan perilaku (afektif menggerakan perilaku). Di sisi lain, pikiran menekankan komponen kognitif untuk menghasilkan penilaian dan perkiraan mengenai perilaku (kognitif menggerakkan perilaku). Dengan berpikir positif, seseorang cenderung menafsirkan permasalahan mereka sebagai hal yang sementara, terkendali, dan hanya khusus untuk satu situasi. 
Menurut Anggraini, Syaf and Murni, (2017) ada hubungan yang signifikan antara berpikir positif dengan kecemasan komunikasi dengan arah hubungan negatif, yang artinya semakin tinggi berpikir positif maka semakin rendah kecemasan komunikasi pada mahasiswa Universitas Abdurrab Pekanbaru dan sebaliknya, semakin rendah berpikir positif maka semakin tinggi kecemasan.(Saputri and Hasyim, 2020)

Menurut pendapat peneliti, Individu yang berpikir positif akan menanggapi dan mengatasi persoalan secara lebih optimis dan mengarahkan pikirannya pada hari depan yang gemilang. Dengan demikian bila individu berada dalam masa-masa penuh kesulitan, sehingga individu akan mempunyai sikap untuk selalu menanggapi dan mengatasi persoalannya secara optimis maka sikap yang demikian itu telah membantu mengubah saat-saat gelap menjadi lebih cerah, produktif dan kreatif. Dengan demikian kecemasan berbicara di depan umum diharapkan dapat diminimalisir jika individu atau siswa selalu berpikir positif, karena dalam berpikir positif siswa tidak hanya dapat membebaskan diri dari rasa cemas yang berkepanjangan, tetapi juga akan mampu menghilangkan berbagai perasaan negatif seperti takut salah atau ditertawakan, malu, merasa tidak bisa dan rendah diri dan lain sebagainya.

\section{SIMPULAN}

Berdasarkan hasil penelitian dapat dilihat bahwa ada hubungan antara self efficacy dan berfikir positif dengan kecemasan berbicara di depan umum pada mahasiswa. Hal ini menunjukkan korelasi yang negative yang berarti semakin tinggi self efficacy dan berfikir positif maka akan semakin menurunkan kecemasan mahasiswa untuk berbicara di depan umum bagi mahasiswa STIKes Muhammadiyah Pringsewu.

\section{SARAN}

Disarankan bagi Mahasiswa dapat terus meningkatkan self efficacy dan meningkatkan kemampuan berpikir positif untuk mengurangi kecemasan berbicara di depan umum dengan cara mengedepankan perhatian positif dan ungkapan positif terhadap berbagai hal.

\section{DAFTAR PUSTAKA}

Adriansyah, M. A., Rahayu, D. and Prastika, N. D. (2015) 'Pengaruh terapi berpikir positif dan cognitive behavior therapy (cbt) terhadap penurunan kecemasan pada mahasiswa universitas mulawarman 1)', Jurnal Psikostudia Universitas Mulawarman, 4(2), pp. 105-125.

Anggraini, Y., Syaf, A. and Murni, A. (2017) 'Hubungan antara berpikir positif dengan kecemasan komunikasi pada mahasiswa', PSYCHOPOLYTAN (Jurnal Psikologi), 1(1), pp. 31-38.

Arsy, H. (2011) 'Hubungan Berpikir Positif dengan Kecemasan Menghadapi Masa Depan Pada Mahasiswa Fakultas Psikologi UIN Suska Riau', Skripsi, Fakultas PSikologi UIN Sultan Syarif Kasim Riau, pp. 9-39.

Bukhori, B. (2016) 'Kecemasan Berbicara di Depan Umum Ditinjau dari Kepercayaan Diri dan Keaktifan Dalam Organisasi Kemahasiswaan', Jurnal Komunikasi Islam, 6(1), pp. 158-186.

Dharma, K. (2015) Metodologi Penelitian Keperawatan: Pedoman Melaksanakan Dan Menerapkan Hasil Penelitian. Jakarta: CV Trans Info Media. 


\section{(JIK) JURNALLLMAA KESEEATTAN}

Vol 10 No 2 Juli 2021 | Page 106-112

Elfiky, I. (2009) Terapi Berpikir Positif. Jakarta: Zaman.

Gündüz, B. (2012) 'Self-efficacy and burnout in professional school counselors', Kuram ve Uygulamada Egitim Bilimleri, 12(3), pp. 1761-1767.

Haziqatuzikra and Nio, S. R. (2018) 'Hubungan self-efficacy dengan kecemasan berbicara di depan umum pada mahasiswa kpi uinib padang', kpi uinib padang.

Mardhika, R. (2016) 'HUBUNGAN POLA PIKIR NEGATIF DAN KECEMASAN TERHADAP CARA BERBICARA DI DEPAN UMUM MAHASISWA PROGRAM STUDI PENDIDIKAN KEPELATIHAN OLAHRAGA', Jurnal Buana Pendidikan, 12(22), pp. 88-98.

McCroskey (2013) 'The communication apprehension Perspective'.

Muslimin, K. and Mahasiswa (2013) 'Faktor - Faktor yang Memengaruhi Kecemasan Berrkomunikasi di Depan Umum ( Kasus Mahasiswa Fakultas Dakwah INISNU Jepara ) Khoirul Muslimin', JURNAL INTERAKSI, 2(2), pp. 42-52.

Prakoso, B. (2014) 'HUBUNGAN ANTARA BERPIKIR POSITIF DENGAN KECEMASAN BERBICARA DI DEPAN UMUM', Fakultas Psikologi, UMS

Saputri, N. and Hasyim, D. I. (2020) 'Optimalkan Kecerdasan Anak dengan Bermain', 3(2), pp. 1621.

Sugiyono (2016) Statistika untuk penelitian. Bandung. Bandung: CV Alfabeta.

Wahyuni, E. (2015) 'Hubungan Self-Effecacy dan Keterampilan Komunikasi dengan Kecemasan Berbicara di Depan Umum', Jurnal Komunikasi Islam, 05(1-32).

Wahyuni, S. (2013) 'Hubungan antara kepercayaan diri dengan kecemasan berbicara di depan umum pada mahasiswa psikologi’, Psikoborneo, 1(4), pp. 220-227. 